\title{
O autor como gesto. À memória de Ronaldo Assunção
}

Em seu último livro de ensaios, Profanazioni, que é uma tentativa de retirar os homines sacri de seu círculo de indecidibilidade, o filósofo italiano Giorgio Agamben evoca a famosa conferência de Foucault $O$ que é um autor? Relembra Agamben a drástica separação que Foucault estabelecia entre a função-autor e o autor como indivíduo, e que o levara a repetir, em várias oportunidades, que a marca do escritor residia na singularidade de sua ausência, aguardando-lhe, no jogo escriturário, o papel de morto. L'autore non è morto - frisa Agamben - ma porsi come autore significa occupare il posto di un morto.

O próprio Agamben relembra também que o único texto em que as aporias dessa divisão entre o sujeito e a função do autor se manifestam mais explicitamente é o ensaio em que Michel Foucault problematiza a temática da vida, ou seja, o prefácio que ele escreve para um volume, não editado, sobre os homens infames. Na esteira de História da loucura, Foucault empreende, com a historiadora Arlette Farge, a compilação de uma antologia das biografias de criminosos, fora-da-lei e bandidos de todo tipo conservadas nos arquivos do Hospital Geral e da Bastilha. No prefácio em questão, Foucault estipula a gênese dessa ontologia de nós mesmos que ele perseguia como chave da modernidade.

Nesse texto preliminar, mas também derradeiro, Foucault usa a vida - la vie au-delà de la vie, la vie plus que la vie, como diria Derrida - para definir a literatura, com que o modelo da ficção, tal como investigado à época de As palavras e as coisas, transforma-se no modelo de uma sur-littérature, uma literatura que sobrevive à própria literatura. Nesse tal prefácio para $A$ vida dos homens infames, Foucault oferece, então, uma bela e sucinta definição de literatura, ao estipular que

a fábula, no sentido estrito da palavra, é o que merece ser dito. Durante muito tempo, na sociedade ocidental, a vida de todos os dias não pôde ter acesso ao discurso a não ser atravessada e transfigurada pelo fabuloso; era necessário que saísse de si própria por meio do heroísmo, as proezas, as aventuras, a providência e a graça, ou, eventualmente, o crime; era preciso que estivesse marcada por um toque de impossibilidade. Só então essa vida se tornava algo que podia ser dito, o que a colocava numa situação inacessível que lhe permitia, ao mesmo tempo, funcionar como lição e como exemplo. Conforme ela se afastava do ordinário, a narrativa adquiria maior força para enfeitiçar ou persuadir. Nesse jogo do 
“fabuloso-exemplar”, a indiferença com relação ao verdadeiro e o falso era, portanto, fundamental. E se, por vezes, empreendia a tarefa de deixar transparecer en si mesma a mediocridade do real, tratava-se tão-somente de um recurso para provocar um efeito cômico: o simples fato de falar disso levava ao riso.

A partir do século XVII, o Ocidente viu nascer toda uma "fábula" da vida obscura da qual o fabuloso fora proscrito. O impossível ou o irrisório deixaram de ser a condição necessária para narrar o ordinário. Nasce, assim, uma arte da linguagem cuja tarefa consiste não em cânticos ao improvável, mas em fazer aparecer o que permanecia oculto, o que não podia ou não devia vir à tona, ou, em outras palavras, os graus mais baixos e mais persistentes do real. No momento em que começa a funcionar um dispositivo para obrigar a dizer o "ínfimo", o que não se diz, o que não merece nenhuma glória e, portanto, o "infame”, cria-se um novo imperativo que constitui aquilo que poderia ser denominado a ética imanente do discurso literário do Ocidente: suas funções cerimoniais apagam-se progressivamente; ele já não terá como objetivo manifestar de forma sensível o fulgor demasiado visível da força, da graça, do heroísmo, do poder, mas irá buscar aquilo que é mais difícil de captar, o mais oculto, o que mais custa dizer e mostrar, em última análise, o mais proibido e o mais escandaloso. Uma espécie de exortação, voltada a extrair a parte mais noturna e a mais cotidiana da existência, vai traçar - mesmo que assim se descubram por vezes as figuras solenes do destino - a linha de evolução da literatura a partir do século XVII, a partir do momento em que ela começou a ser literatura no sentido moderno da expressão. Mais que uma forma específica, mais que uma relação essencial quanto à forma, essa imposição, ia quase dizer esta moral, é o que a caracteriza e conduz até nós, em um imenso movimento, a obrigação de dizer os segredos mais corriqueiros. A literatura não absorve para si essa enorme política, essa grande ética discursiva; nem mesmo se reduz a ela por inteiro, mas encontra nela seu lugar e suas condições de existência.

Daí a dupla relação que a literatura mantém com a verdade e com o poder. Enquanto o fabuloso não pode funcionar fora de uma indecisão entre o verdadeiro e o falso, a literatura se instaura em uma decisão de não-verdade: ela se oferece, explIcitamente, como artifício, porém comprometendo-se a produzir efeitos de verdade que são, como tais, perceptíveis. A importância que, na época clássica, concedeu-se ao natural e à imitação constitui, sem dúvida, uma das primeiras maneiras de formular esse funcionamento "de verdade" da literatura. Daí em diante, a ficção substitui o fabuloso; o romance se liberta do fantástico e só se desenvolverá libertando-se, por completo, de suas prisões. A literatura faz parte, portanto, desse enorme sistema de coação que, no Ocidente, fez o cotidiano passar à ordem do discurso, porém a literatura ocupa nele um lugar especial: consagrada a buscar o cotidiano para além de si próprio, a trasgredir os limites, a descobrir, de forma brutal ou insidiosa, os segredos, a deslocar as regras e os códigos, a obrigar-se a dizer o inconfessável, ela terá, portanto, que se situar, ela própria, fora da lei, ou, ao menos, fazer com que sobre ela recaia a carga do escândalo, da transgressão ou da revolta. Mais que qualquer outra forma de linguagem, a literatura continua sendo o discurso da "infâmia”, a ela 
corresponde dizer o mais indizível, o pior, o mais secreto, o mais intolerável, o desavergonhado.

Ora, essas considerações levam Agamben a concluir que um autor assinala tão-somente uma vida que foi jogada na obra - e que foi jogada como obra. Para ilustrar essa noção de autor como gesto, o filósofo se vale do verso inicial do "Redobre fúnebre pelos escombros de Durango", o poema XIII de Espanha, afasta de mim este cálice. Fiel ao princípio mallarmaico de que rien n'aura lieu que le lieu, Agamben se questiona se o sentido desse verso - "Padre pó, tu que sobes da Espanha" - veio antes ou depois de Vallejo escrever o verso. Nada nos garante que ele tenha primeiro imaginado e depois escrito o verso que nos comove. Aliás, essa hipótese (o sujeito precede sempre o texto) é a menos plausível de todas que porventura imaginemos. É bem mais provável que só depois de ter escrito essas palavras o sentimento que elas encerram tenha se tornado real para o indivíduo César Vallejo, o que leva Agamben a concluir que il luogo - o, piuttosto, l'aver luogo-del poema non è, dunque, né nel testo, né nell'autore (o nel lettore): è nel gesto in cui autore e lettore si mettono in giocco nel testo e, insieme, infinitamente se ne rittraggono, de tal modo que o autor é tão-somente a testemunha, o fiador de sua própria ausência na obra, cabendo ao leitor, por sua vez, retraçar essa ausência como infinito recomeço do jogo.

Trouxe essas considerações de Agamben à baila não apenas por compartilhar suas idéias, mas também porque elas são uma homenagem a um poeta muito admirado, César Vallejo. E, indiretamente, por estarem ligadas a um admirador de sua poesia, Ronaldo Assunção.

Quando conheci Ronaldo, uma coisa era clara e já estava decidida de antemão: ele queria trabalhar a poesia de Vallejo. Desse jogo duplo, o ir e vir da escritura que se foi tramando no convívio acadêmico, como um gesto in cui autore e lettore si mettono in giocco nel testo e, insieme, infinitamente se ne rittraggono, foi se construindo também uma reflexão sobre as viagens de um infame como Vallejo pelas cidades modernas do século XX - ainda Paris, obviamente, mas sobretudo Moscou, como promessa de felicidade futura. Desse esforço saiu um mestrado, defendido na Universidade Federal de Santa Catarina há dez anos, e fundamentalmente um livro: Arte e experiência urbana em César Vallejo. Paris-Moscou 1923-1938. Quase no fim do ensaio, Ronaldo resumia sua intenção ao escrevê-lo, e nos lembrava que:

A relação que o poeta latino-americano César Vallejo demarca, nos anos em que viveu na metrópole européia, particularmente, impõe-se pelas constantes rupturas advindas ora pela existência conturbada de sua vida, ora pela profunda consciência que tinha dos problemas do seu tempo. Se Paris recorta-se como o espaço da experiência e da reflexão estética, Moscou, por seu turno, recorta-se como a possibilidade de saída desse impasse de crise não só política e social, 
como também estética. Ambas as experiências, ainda que tenham contribuído para o amadurecimento de suas concepções intelectuais, não satisfizeram as suas expectativas. É nesse espaço de esperança e desilusão que se debate o poeta. Vallejo, como homem e como artista, desponta, no contex to latino-ameticano, como ponto de dissensão e reflexão. Oferece, assim, novos elementos para entender-se e redescobrir-se a tradição política e literária latino-americana.

E, voltando ao silêncio de onde emergira seu questionamento primeiro, Ronaldo Assunção concluía seu livro de maneira simétrica a seu início, isto é, lendo a trajetória do artista viajante como um rio que flui infinitamente, deixando, nas suas margens, fragmentos, detalhes, pedaços heterogêneos que traduzem uma estética do ensaio, do "borrador", de verdades em suspenso, que simbolizam, precisamente, o profundo compromisso do artista com a arte, com o mundo, enfim, com "el movimiento y el reposo de la vida". A poesia é a tradução mais completa da fragilidade da história e da vida; da impossibilidade de entender-se tudo e totalizar. Como diz Vallejo, "la historia no se narra ni se mira ni se escucha ni se toca. La historia se vive y se siente vivir". E em seu fabuloso livro borrador, Contra el secreto profesional, o poeta define a derradeira condição dos homens no mundo e sua fragilidade, e com isso eu termino: "en realidad, el cielo no queda lejos ni cerca de la tierra. En realidad, la muerte no queda ni cerca ni lejos de la vida. Estamos siempre ante el río de Heráclito”.

Veio depois uma reflexão de Ronaldo sobre Mário de Andrade e Jorge Luís Borges, dois autores que ele passou a freqüentar nesses cursos iniciais. Talvez ao ler, après-coup, seu ensaio sobre Vallejo, a pungência das palavras aí escritas tenham alimentado nele uma vie au-delà de la vie. Uma vida - uma condição de autor - que, além de efêmera, ficou marcada por uma condição (tão Antonio Machado...) própria de Ronaldo Assunção como hombre bueno. Ronaldo teve a força (a coragem) de se pensar maior do que era, maior do que suas limitações de tempo e lugar. Sonhou. Viveu. Fez-se autor. Adotou um gesto. Sei que ele gostaria de ouvir mais uma vez, na tradução de Thiago de Mello, o sermão que Vallejo nos deixou sobre a morte:

E, enfim, passando logo ao domínio da morte, que atua em esquadrão, colchete prévio, parágrafo e chave, mão grande e diérese, por que a escrivaninha assíria, por que o púlpito cristão, o intenso abalo do móvel vândalo ou, ainda menos, este esdrúxulo retiro?

É para termirar, amanhã, em protótipo de alarde fálico, em diabete, em urinol branco, em rosto geométrico, em defunto, que se fazem mister sermão e amêndoas, que sobram literalmente batatas e este espectro fluvial em que arde o ouro 
e em que se queima o preço da neve?

É para isso que morremos tanto?

Só para morrer

é preciso morrer a cada instante?

E o parágrafo que escrevo?

E o colchete deísta que desfraldo?

E o esquadrão em que meu elmo foi inútil?

E a chave que dá em todas as portas?

$\mathrm{E}$ a forense diérese, a mão,

minha batata e minha carne, e minha contradição sob o lençol.

Louco de mim, lobo de mim, cordeiro

de mim, sensato, cavalíssimo de mim!

Escrivaninha, sim, a vida toda. Púlpito,

também, por toda a morte.

É sermão da barbárie: estes papéis;

esdrúxulo refúgio: este meu couro.

De tal modo, cogitabundo, aurífero, braçudo,

defenderei minha presa em dois momentos,

com a voz e também com a laringe,

e do olfato físico com que oro

e do instinto de imobilidade com que ando,

me honrarei enquanto viva - convém dizer;

se orgulharão as minhas varejeiras

porque no centro estou, mas à direita

também estou, e à esquerda estou também

Raul Antelo

[UFSC]. 